\title{
PERSEPSI RISIKO COVID-19 TERHADAP INTENSI BERWISATA DI JABODETABEK
}

Submitted Date :

4 November 2020

Accepted Date :

10 November 2020
Fredy Utama Sekolah Bisnis dan Ekonomi, Universitas Prasetiya Mulya fredy.utama@prasetiyamulya.ac.id

Doddy Setiawan

Universitas Sebelas Maret doddy.setiawan@staff.uns.ac.id

\section{Suggested Citation:}

Jun, S. H. (2020). The effects of perceived risk, brand credibility and past experience on purchase intention in the Airbnb context. Sustainability (Switzerland), 12(12). https://doi.org/10.3390/su12125212

\section{Abstract:}

Since the Covid-19 pandemic has been declared as a global pandemic, tourism was the most affected sector by pandemic Covid-19. For the tourism industry, there are direct consequences for the national and local restrictions that have a direct impact on people's lives to minimize the spread of the virus. There are human mobility and the possibility of direct physical contact between individuals. Several things that are considered by tourists in making travel decisions, including the risk perception and their travelling's safety to a destination. There are several risk perceptions, namely the financial risk perception, time risk, social-psychological risk and health risk. Hypothesis using SEM AMOS to majority 16-25 years old respondents, found no direct influence between perceived risk and intention to travel. The results showed that an increase in risk perception did not affect a decrease in travel intention. Among the 4 variables tested, perceptions of financial risk have the greatest influence, followed by perceptions of health risk, social-psychological risk and time risk.

Keyword : Covid-19, Risk Perception, Travel Intention

\section{Abstrak:}

Semenjak pandemi Covid-19 diumumkan sebagai pandemi global, sektor pariwisata adalah sektor yang terkena dampak pandemi Covid-19. Bagi industri pariwisata terdapat konsekuensi langsung terhadap pembatasan lokal dan nasional yang telah diterapkan pada kehidupan masyarakat untuk memerangi penyebaran virus yaitu konsekuensi terhadap mobilitas dan kemungkinan berhubungan langsung secara fisik antar individu. Beberapa hal yang dipertimbangkan oleh wisatawan dalam pengambilan keputusan berwisata diantaranya adalah persepsi wisatawan tentang risiko dan keamanan mereka untuk bepergian ke suatu tujuan. Ada beberapa persepsi risiko yang dipikirkan para wisatawan yaitu persepsi risiko keuangan, risiko waktu, risiko sosial psikologi dan risiko kesehatan. Uji hipotesa yang dilakukan dengan menggunakan SEM AMOS terhadap mayoritas responden berusia 16-25 tahun, ditemukan tidak adanya pengaruh langsung antara persepsi risiko terhadap intensi berwisata. Hasil penelitian menunjukan peningkatan persepsi risiko tidak mempengaruhi penurunan terhadap intensi berwisata. Diantara 4 variabel yang diuji, persepsi risiko keuangan memiiki pengaruh yang paling besar, diikuti oleh persepsi risiko kesehatan, risiko sosial psikologi dan terakhir risiko waktu.

Kata Kunci: Covid-19, Risk Perception, Travel Intention

\section{JEL Classification: L83; M31}




\section{Pendahuluan}

Pandemi Covid-19 adalah peristiwa menyebarnya penyakit korona virus 2019. Terdata per 8 Agustus 2020 kasus positif COVID-19 terkonfirmasi di Indonesia mencapai 123,503 orang, 5,658 meninggal, dan 79,306 sembuh (Kompas, 2020). Sejak kasus Covid-19 pertama kali terdeteksi di Indonesia di bulan Maret 2020, Indonesia menetapkan pembatasan social dalam skala besar (PSBB) dalam tanggal 31 Maret 2020. Hal ini sesuai dengan peraturan pemerintah Nomer 21 Tahun 2020. DKI Jakarta pada tanggal 10 April 2020 melakukan penerapan PSBB. Pada tanggal 4 Juni 2020, Provinsi DKI Jakarta menerapkan PSBB Masa Transisi. Sebagai bagian dari penerapan PSBB masa transisi, sektor pariwisata dalam hal ini, taman rekreasi indoor, taman rekreasi outdoor dan kebun binatang mulai dibuka pada tanggal 20-21 Juni dengan kapasitas maksimal $50 \%$.

Semenjak pandemi Covid-19 diumumkan sebagai pandemi global, sektor pariwisata adalah sektor yang terkena dampak pandemi Covid-19. Bagi industri pariwisata terdapat dua hal penting dan terlihat dari konsekuensi dan tindakan terhadap, pembatasan yang telah diterapkan pada kehidupan masyarakat untuk memerangi penyebaran virus yaitu keterbatasan mobilitas dan peluang berkontakan secara fisik antar individu. Wisatawan memiliki beberapa pertimbangan dalam pengambilan keputusan untuk berwisata. Persepsi wisatawan tentang risiko dan keamanan merupakan salah satu faktor kunci dalam proses pengambilan keputusan mereka untuk bepergian ke suatu tujuan (Gut \& Jarrell, 2007; Rittichainuwat \& Chakraborty, 2009)

Beberapa penelitian yang berhubungan dengan pariwisata sudah banyak yang membahas hubungan antara motivasi berlibur dan persepsi risiko. Para peneliti pariwisata mengklasifikasikan persepsi risiko dalam beberapa cara. Dalam pariwisata medis misalnya, persepsi risiko dapat mempengaruhi wisatawan medis menghindari tujuan tertentu atau bahkan ada kecenderungan untuk tidak bepergian sama sekali (Mohammad J. Khan et al., 2017). Penelitian yang dilakukan oleh (Khasawneh \& Alfandi, 2019) mengidentifikasi bahwa dua dimensi persepsi risiko (yaitu risiko keuangan dan risiko performansi) berdampak signifikan pada total citra destinasi. Sedangkan persepsi risiko fisik, waktu dan risiko sosial psikologi tidak begitu penting berdampak pada citra destinasi.

Sedangkan Moutinho (2007) membahas ada 4 kelompok persepsi risiko yang dipikirkan para wisatawan pada saat pengambilan keputusan berlibur mereka yaitu perang dan ketidakstabilan politik, masalah kesehatan, kejahatan dan serangan teroris. Lebih lanjut Hasan et al. (2017) mengkategorikan persepsi risiko menjadi enam dimensi yaitu risiko fisik, risiko keuangan, risiko performansi, risiko sosial, risiko psikologi and risiko keuangan. Lalu bagaimana dengan risiko kesehatan? Apakah risiko kesehatan, dalam hal ini, menyebarnya, pandemi Covid-19, berpengaruh kepada keinginan untuk berwisata?

Penelitian ini dilakukan untuk melihat pengaruh dari persepsi risiko dari penduduk Jabodetabek terhadap intensi berwisata di beberapa tempat destinasi di Jakarta dan risiko yang paling mempengaruhi keputusan berlibur. Penelitian ini juga ingin melihat apakah pandemi Covid-19 mempengaruhi keinginan wisatawan untuk berlibur.

\section{Kajian Literatur}

\section{Persepsi Risiko}

Persepsi risiko dalam pariwisata didefinisikan sebagai persepsi setiap individu mengenai kemungkinan adanya suatu tindakan dapat memaparkan suatu bahaya yang dapat mempengaruhi keputusan perjalanan (Chew \& Jahari, 2014). Semua risiko diduga berasal dari risiko kinerja, risiko produk tidak sesuai yang diharapkan, yang mengarah pada persepsi kerugian finansial, waktu, kesehatan, dan psikososial (Featherman \& Pavlou, 2003). Loewenstein et al. (2001) memperkenalkan teori risk-as-feeling, yang menekankan dampak persepsi risiko afektif pada perilaku tertentu.

Dalam pariwisata, risiko telah diteliti sebagai perhatian utama bagi wisatawan (Kozak et al., 2007). Karena seseorang secara inheren mengejar kebutuhan akan keselamatan dan keamanan ketika membuat keputusan perjalanan dalam keadaan risiko yang tidak pasti (Beirman, 2002).Para peneliti telah memperluas bidang penelitian dengan memeriksa hubungan antara pengetahuan turis sebelumnya, persepsi risiko, dan perilaku pencarian informasi (Sharifpour et al., 2014). Kekhawatiran wisatawan dapat bervariasi sebagai fungsi dari faktor situasional, yang bergantung pada pengalaman dan harapan individu dari elemen-elemen ini (Choi et al., 2019). Pengambilan keputusan perjalanan dinilai rumit karena karakteristiknya. Layanan dalam industri pariwisata tidak dapat diuji atau dirasakan sebelum dibeli, dan oleh karena itu biaya yang dikeluarkan sebelum merasakan perjalanan tidak dapat dipulihkan jika harapan atau ekspektasi tidak terpenuhi. Oleh karena itu, wisatawan dihadapkan pada beberapa tingkat risiko finansial (Sonmez \& Graefe, 1998). 
Artuğer (2015) berpendapat bahwa perjalanan dan pariwisata bahkan lebih rentan terhadap risiko dan ketidakpastian. Karena perjalanan mungkin bukan kebutuhan hidup utama, wisatawan lebih sensitif terhadap risiko dan masalah keamanan bersedia untuk menunda atau membatalkan rencana perjalanan mereka untuk menghindari risiko yang diperkirakan. Hal ini semakin relevan saat ini, karena pandemi yang melanda seluruh dunia yaitu Covid-19.

\section{Risiko Keuangan}

Dalam lingkungan bisnis dalam situasi pandemi Covid-19, risiko dan ketidakpastian telah mendapat perhatian lebih dari sebelumnya. Ming-Yuan (2006) menekankan bahwa dalam bidang manajemen keuangan, globalisasi keuangan dan risiko keuangan selalu berhubungan satu sama lain. Risiko Keuangan merupakan risiko dari wisatawan mengenai kemungkinan kehilangan uang atau manfaat uang maksimal dari aktiftasnya (Garner, 1986). Risiko keuangan juga merupakan risiko yang paling penting dalam destinasi hotel (Mitchell \& Vassos, 1998). Persepsi risiko perjalanan telah menjadi topik penting di industri pariwisata dalam beberapa dekade terakhir karena krisis yang sedang berlangsung di seluruh dunia. Pengaruh persepsi risiko perjalanan terhadap niat perjalanan telah ditetapkan dalam literatur dan diakui secara luas bahwa wisatawan pada umumnya lebih suka memilih tujuan yang aman, damai, dan stabil untuk liburan mereka (Promsivapallop \& Kannaovakun, 2018). Oleh karena itu, terbentuklah hipotesa pertama, yaitu:

\section{H1: Peningkatan Risiko Keuangan berdampak negatif terhadap Intensi Berwisata}

\section{Risiko Waktu}

Menurut Quintal et al. (2010), persepsi risiko mengacu pada persepsi kemungkinan kerugian karena ketidakpastian dalam pembelian produk atau layanan. Risiko waktu merupakan mengenai kemungkinan wisatawan mengalami pengalaman perjalanan hanya membuang-buang waktu atau kekhawatiran risiko waktu bahwa penggunaan produk atau layanan akan memakan waktu terlalu lama. Mitchell \& Vassos (1998), berpendapat kehilangan waktu berarti waktu yang hilang yang diakibatkan karena kegagalan produk dalam memenuhi kebutuhan atau bisa juga berarti waktu yang diperlukan untuk memperbaiki kegagalan tersebut. Oleh karena itu, terbentuklah hipotesa kedua, yaitu:

\section{H2: Peningkatan Risiko Waktu berdampak negatif terhadap Intensi Berwisata}

\section{Risiko Sosial Psikologi}

McLeay et al (2018) mendefinisikan risiko psikologi sebagai sebagai kecemasan dan atau ketidaknyamanan perasaan yang timbul dari emosi pasca-perilaku yang diantisipasi seperti kekhawatiran dan ketegangan. Sedangkan risiko social didefinisikan sebagai potensi hilangnya harga diri, rasa hormat, dan persahabatan yang ditawarkan kepada konsumen oleh individu lain (Laroche et al., 2004). Oleh karena itu, terbentuklah hipotesa keempat yaitu:

\section{H3: Peningkatan Risiko Sosial-Psikologi berdampak negative terhadap Intensi Berwisata}

\section{Risiko Kesehatan}

Wabah Penyakit Coronavirus (Covid-19) telah menjadi krisis kesehatan global dengan konsekuensi yang luas dan menghancurkan bagi individu dan masyarakat. Baik penelitian sebelumnya maupun temuan baru-baru ini menunjukkan bahwa epidemi dan pandemi penyakit menular bisa menjadi pengalaman yang sangat traumatis bagi beberapa individu dan tekanan psikologis kronis. Sementara pandemi penyakit menular bisa sangat membuat stres bagi semua individu, penelitian menunjukkan bahwa dampak psikologis dari kolektif ini mungkin lebih parah untuk beberapa individu karena faktor risiko tertentu, seperti paparan penyakit yang lebih besar (Boyraz \& Legros, 2020).

Menurut Neuburger et al. (2020), pariwisata merupakan sektor yang paling terdampak wabah Covid-19. Sebelumnya, krisis kesehatan telah mempengaruhi ekonomi pariwisata dan perilaku perjalanan wisatawan seperti wabah SARS (Pine \& McKercher, 2004). Risiko kesehatan yang dirasakan terdiri dari kerentanan yang dirasakan seseorang terhadap penyakit dan keparahan yang dirasakan (Floyd et.al., 2000). Kerentanan mengacu pada risiko tertular suatu penyakit (Brewer \& Fazekas, 2007). Individu, yang merasa berisiko tertular penyakit, akan melakukan tindakan untuk mencegah risiko ini seperti menghindari perjalanan (Brewer et al., 2007).

Risiko kesehatan dapat didefiniskan sebagai risiko subyektif terjadinya peristiwa negatif terkait kesehatan baik untuk seseorang ataupun sekelompok orang dalam jangka waktu tertentu. Pengaruh persepsi risiko 
penyakit virus korona-19 (Covid-19) pada niat perilaku terhadap pariwisata 'untact' di Korea Selatan selama gelombang pertama pandemi di bulan Maret tahun 2020. Bae \& Chang (2020) mempelajari pengaruh risiko kesehatan dari aspek kognitif dan afektif. Hasil penelitian yang dilakukan Bae \& Chang (2020) menunjukkan bahwa persepsi risiko afektif terhadap penyakit korona-19 mempengaruhi secara signifikan dari sikap berwisata, sedangkan persepsi risiko kognitif berpengaruh positif terhadap norma subjektif. Dari beberapa temuan, muncul hipotesa ketiga, yaitu:

\section{H4: Peningkatan Risiko Kesehatan berdampak negatif terhadap Intensi Berwisata}

\section{Intensi Berwisata}

Intensi untuk berwisata digambarkan sebagai kemungkinan untuk mengunjungi suatu tujuan atau destinasi wisata di waktu yang berdekatan (Matzler et al., 2016). Pada penelitian sebelumnya, jika persepsi risiko dalam mengunjungi suatu destinasi meningkat, sikap wisatawan terhadap kunjungan ke destinasi tersebut menjadi lebih negative (Quintal et al., 2010). Pada tahun 2019 hingga tahun 2020, dapat dipastikan persepsi individu tentang risiko kesehatan atau fisik meningkat dengan munculnya pandemi Covid-19 di seluruh dunia termasuk Indonesia yang berpengaruh besar dalam industri pariwisata. Secara khusus, penyakit serius seperti SARS, flu burung, dan MERS telah sangat mempengaruhi industri pariwisata, mulai dari dampak ekonomi serta pengaruhnya terhadap niat perjalanan (Lee et al., 2012).

Menurut Reisinger \& Mavondo (2005), tingkat kecemasan memiliki pengaruh yang signifikan terhadap persepsi keselamatan dan akhirnya pada niat bepergian. Niat untuk bepergian ditentukan oleh tingkat kecemasan dan keamanan perjalanan (Choi et al., 2019). Ketika calon wisatawan menganggap suatu tujuan kurang aman karena risiko, mereka dapat menyesuaikan perilaku perjalanan mereka, memperoleh informasi tambahan tentang suatu tujuan, atau bahkan mengubah tujuan mereka (Reisinger \& Mavondo, 2005).

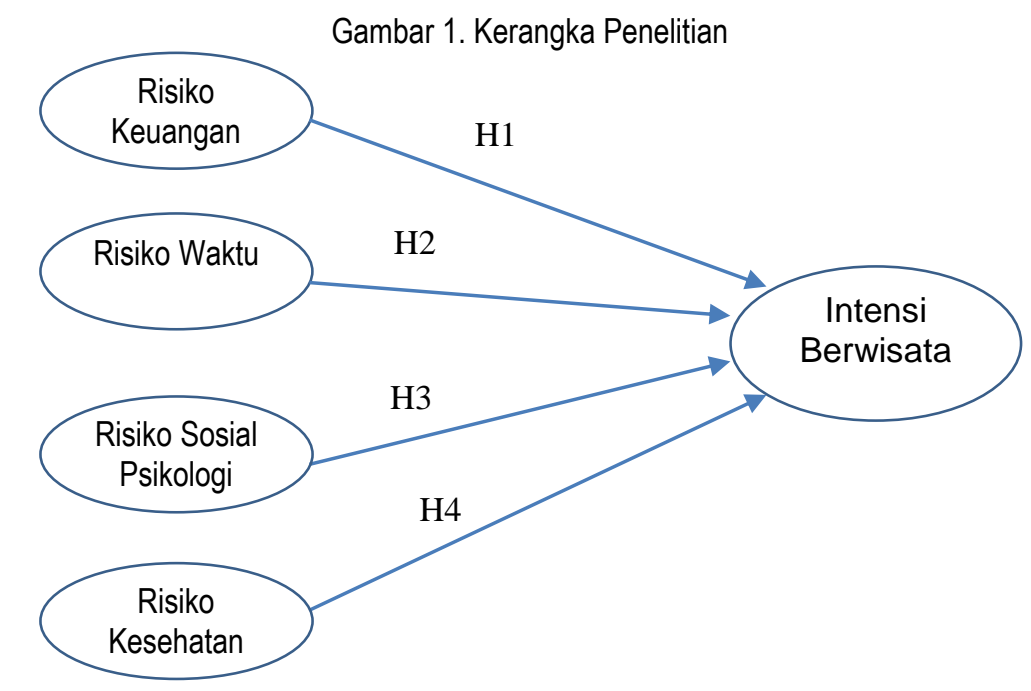

\section{Metode Penelitian}

Penelitian ini mengunakan non probability sampling dalam pengambilan sample data penelitiannya. Dengan menggunakan snowball sampling, data diambil mulai dari jumlah kecil dan kemudian disebarkan dari sampel awal atas dasar preferensi sampai memenuhi jumlah sampel minimum (Sugiyono, 2001). Peneliti menyebarkan kuesioner secara online kepada masyarakat Jabodetabek. Jika responden yang menjawab berada diluar wilayah tersebut maka peneliti akan mengeluarkan hasil daripada jawaban responden tersebut. Jumlah sampel yang digunakan dalam penelitian ini adalah 120 orang. Hal ini sesuai dengan jumlah minimal sampel yang dibutuhkan dan juga jumlah sampel yang berada antara 100 dan 200 (Hair et al.,1998).

Peneliti mengambil sejumlah instrumen dari jurnal yang telah diuji dan sering kali digunakan oleh penelitian lainnya. Adapun beberapa instrumen penelitian adalah sebagai berikut: 
Tabel 1. Instrumen Penelitian

\begin{tabular}{|c|c|c|c|}
\hline Variabel & Kode & Indikator & Referensi \\
\hline \multirow[t]{4}{*}{$\begin{array}{l}\text { Risiko } \\
\text { Keuangan }\end{array}$} & RF1 & $\begin{array}{l}\text { Saya khawatir harga tiket tempat destinasi wisata (misal Ancol, } \\
\text { Taman Mini dan lain sebagainya) yang ingin saya kunjungi lebih } \\
\text { mahal daripada harga tempat destinasi yang lain }\end{array}$ & \multirow{13}{*}{$\begin{array}{l}\text { S. H. Jun (2020); } \\
\text { Mohammad Jamal } \\
\text { Khan et al. (2019); } \\
\text { Mohammad Jamal } \\
\text { Khan et al, (2017) }\end{array}$} \\
\hline & RF2 & $\begin{array}{l}\text { Saya khawatir tempat destinasi wisata (misal Ancol, Taman Mini } \\
\text { dan lain sebagainya) terlalu mahal mengingat kualitas yang } \\
\text { ditawarkan }\end{array}$ & \\
\hline & RF3 & $\begin{array}{l}\text { Saya khawatir berwisata di tempat destinasi wisata (misal Ancol, } \\
\text { Taman Mini dan lain sebagainya) yang ingin saya kunjungi } \\
\text { menyebabkan kerugian finansial }\end{array}$ & \\
\hline & RF4 & $\begin{array}{l}\text { Saya merasa jika saya bepergian ke tempat destinasi wisata (misal } \\
\text { Ancol, Taman Mini dan lain sebagainya) saya akan mengeluarkan } \\
\text { biaya tidak terduga }\end{array}$ & \\
\hline \multirow[t]{3}{*}{ Risiko Waktu } & RW1 & $\begin{array}{l}\text { Berwisata ke tempat destinasi wisata (misal Ancol, Taman Mini dan } \\
\text { lain sebagainya) akan membuang buang waktu saya }\end{array}$ & \\
\hline & RW2 & $\begin{array}{l}\text { Berwisata di tempat destinasi wisata (misal Ancol, Taman Mini dan } \\
\text { lain sebagainya) akan menyebabkan penggunaan waktu saya tidak } \\
\text { efisien dibandingkan saya mengerjakan aktivitas lain }\end{array}$ & \\
\hline & RW3 & $\begin{array}{l}\text { Saya merasa lebih baik mengerjakan pekerjaan lain dibandingkan } \\
\text { harus ke tempat destinasi wisata (misal Ancol, Taman Mini dan lain } \\
\text { sebagainya) }\end{array}$ & \\
\hline \multirow[t]{6}{*}{$\begin{array}{l}\text { Risiko Sosial } \\
\text { Psikologi }\end{array}$} & RS1 & $\begin{array}{l}\text { Berwisata di tempat destinasi wisata (misal Ancol, Taman Mini dan } \\
\text { lain sebagainya) akan berdampak negatif terhadap opini orang lain } \\
\text { terhadap saya }\end{array}$ & \\
\hline & RS2 & $\begin{array}{l}\text { Saya akan dianggap bodoh oleh orang orang yang pendapatnya } \\
\text { saya hargai jika saya berwisata di tempat destinasi wisata (misal } \\
\text { Ancol, Taman Mini dan lain sebagainya) }\end{array}$ & \\
\hline & RS3 & $\begin{array}{l}\text { Pemikiran untuk berwisata di tempat destinasi wisata (misal Ancol, } \\
\text { Taman Mini dan lain sebagainya) membuat saya merasa tidak } \\
\text { nyaman secara psikologis }\end{array}$ & \\
\hline & RS4 & $\begin{array}{l}\text { Pemikiran untuk berwisata di tempat destinasi wisata (misal Ancol, } \\
\text { Taman Mini dan lain sebagainya) memberikan saya rasa cemas } \\
\text { dan ketegangan yang tidak diinginkan }\end{array}$ & \\
\hline & RS5 & $\begin{array}{l}\text { Tempat destinasi wisata (misal Ancol, Taman Mini dan lain } \\
\text { sebagainya) yang ingin saya kunjungi tidak cocok dengan citra diri } \\
\text { atau konsep diri saya }\end{array}$ & \\
\hline & RS6 & $\begin{array}{l}\text { Bepergian ke tempat destinasi wisata (misal Ancol, Taman Mini } \\
\text { dan lain sebagainya) akan mempengaruhi cara orang lain } \\
\text { memandang diri saya }\end{array}$ & \\
\hline
\end{tabular}




\begin{tabular}{|c|c|c|c|}
\hline Variabel & Kode & Indikator & Referensi \\
\hline & RS7 & $\begin{array}{l}\text { Bepergian ke tempat destinasi wisata (misal Ancol, Taman Mini } \\
\text { dan lain sebagainya) akan menyebabkan kerugian sosial bagi saya } \\
\text { karena saya akan dianggap rendah oleh teman dan kerabat }\end{array}$ & \\
\hline \multirow[t]{5}{*}{$\begin{array}{l}\text { Risiko } \\
\text { Kesehatan }\end{array}$} & RK1 & $\begin{array}{l}\text { Saya khawatir berwisata ke tempat destinasi wisata (misal Ancol, } \\
\text { Taman Mini dan lain sebagainya) akan meningkatkan risiko saya } \\
\text { dan keluarga akan tertular penyakit COVID-19 }\end{array}$ & \multirow{5}{*}{$\begin{array}{l}\text { S. H. Jun (2020); } \\
\text { Mohammad Jamal } \\
\text { Khan et al. (2019); } \\
\text { Mohammad Jamal } \\
\text { Khan et al, (2017); } \\
\text { Bae \& Chang } \\
(2020) \text {; Lee et al., } \\
(2012)\end{array}$} \\
\hline & RK2 & Saya khawatir saya akan tertular COVID-19 & \\
\hline & RK3 & Saya khawatir tentang COVID-19 yang terjadi di wilayah Jakarta & \\
\hline & RK4 & $\begin{array}{l}\text { Saya menahan diri untuk berwisata ke tempat destinasi wisata } \\
\text { (misal Ancol, Taman Mini dan lain sebagainya) yang ingin saya } \\
\text { kunjungi karena orang-orang di sekitar saya sepertinya juga } \\
\text { menahan diri masalah kesehatan }\end{array}$ & \\
\hline & RK5 & $\begin{array}{l}\text { Saya khawatir dengan penanganan kesehatan yang dilakukan oleh } \\
\text { tempat destinasi wisata (misal Ancol, Taman Mini dan lain } \\
\text { sebagainya) yang ingin saya kunjungi }\end{array}$ & \\
\hline \multirow[t]{5}{*}{$\begin{array}{l}\text { Intensi } \\
\text { Berwisata }\end{array}$} & KB1 & $\begin{array}{l}\text { Saya bisa membayangkan menghabiskan liburan saya di tempat } \\
\text { destinasi wisata (misal Ancol, Taman Mini dan lain sebagainya) }\end{array}$ & \multirow{5}{*}{$\begin{array}{l}\text { Choi et al. (2019) ; } \\
\text { Matzler et al. (2016) } \\
\text {; See \& Goh (2019) }\end{array}$} \\
\hline & KB2 & $\begin{array}{l}\text { Saya akan mengerahkan upaya untuk mengunjungi tempat } \\
\text { destinasi wisata (misal Ancol, Taman Mini dan lain sebagainya) di } \\
\text { masa depan }\end{array}$ & \\
\hline & KB3 & $\begin{array}{l}\text { Saya ingin mengunjungi tempat destinasi wisata (misal Ancol, } \\
\text { Taman Mini dan lain sebagainya) yang saya dengar populer di } \\
\text { kalangan keluarga / teman / rekan kerja / agen perjalanan }\end{array}$ & \\
\hline & KB4 & $\begin{array}{l}\text { Saya ingin mengunjungi tempat destinasi wisata (misal Ancol, } \\
\text { Taman Mini dan lain sebagainya) yang populer di rekomendasikan } \\
\text { keluarga / teman / rekan kerja / agen perjalanan saya }\end{array}$ & \\
\hline & KB5 & $\begin{array}{l}\text { Saya ingin mengunjungi tempat destinasi wisata (misal Ancol, } \\
\text { Taman Mini dan lain sebagainya) yang saya dengar dari keluarga / } \\
\text { teman / rekan kerja / agen perjalanan. }\end{array}$ & \\
\hline
\end{tabular}

Sumber : Data Primer Diolah (2020)

Hasil

\section{Uji Validitas}

Dalam melakukan uji reliabilitas, peneliti mengacu pada nilai dari Pearson Correlation yang didapat dari program SPSS dan juga nilai estimate dari hasil standardized regression weights.

Tabel 2. Uji Validitas

\begin{tabular}{lllll} 
& & & $\begin{array}{l}\text { Pearson } \\
\text { Correlation }\end{array}$ & $\begin{array}{l}\text { Standardized Regression } \\
\text { Weights }\end{array}$ \\
\hline RF1 & $<--$ & R_Keuangan & $.864^{* *}$ & 0,859 \\
RF2 & $<--$ & R_Keuangan & $.861^{* *}$ & 0,906 \\
RF3 & $<--$ & R_Keuangan & $.825^{* *}$ & 0,749 \\
RF4 & $<---$ & R_Keuangan & $.757^{* *}$ & 0,606 \\
RW1 & $<---$ & R_Waktu & $.898^{* *}$ & 0,921 \\
\hline
\end{tabular}




\begin{tabular}{|c|c|c|c|c|}
\hline & & & $\begin{array}{l}\text { Pearson } \\
\text { Correlation }\end{array}$ & $\begin{array}{l}\text { Standardized Regression } \\
\text { Weights }\end{array}$ \\
\hline RW2 & $<--$ & R_Waktu & $.923^{* *}$ & 0,894 \\
\hline RW3 & $<--$ & R_Waktu & $.879^{* *}$ & 0,763 \\
\hline RS1 & $<--$ & R_SocPsy & $.893^{* *}$ & 0,893 \\
\hline RS2 & $<--$ & R_SocPsy & $.912^{* *}$ & 0,947 \\
\hline RS3 & $<--$ & R_SocPsy & $.945^{\star \star}$ & 0,945 \\
\hline RS4 & $<--$ & R_SocPsy & $.941^{* *}$ & 0,916 \\
\hline RS5 & $<--$ & R_SocPsy & $.825^{\star *}$ & 0,809 \\
\hline RS6 & $<--$ & R_SocPsy & $.849^{* *}$ & 0,817 \\
\hline RS7 & $<--$ & R_SocPsy & $.909^{* *}$ & 0,888 \\
\hline RK1 & $<--$ & R_Kesehatan & $.875^{* *}$ & 0,888 \\
\hline RK2 & $<--$ & R_Kesehatan & $.919^{* *}$ & 0,934 \\
\hline RK3 & $<--$ & R_Kesehatan & $.872^{* \star}$ & 0,889 \\
\hline RK4 & $<--$ & R_Kesehatan & $.870^{* *}$ & 0,83 \\
\hline RK5 & $<--$ & R_Kesehatan & $.862^{* *}$ & 0,812 \\
\hline KB1 & $<--$ & Intensi_Berwisata & $.563^{* \star}$ & 0,212 \\
\hline KB2 & $<--$ & Intensi_Berwisata & $.773^{\star *}$ & 0,573 \\
\hline KB3 & $<--$ & Intensi_Berwisata & $.856^{* *}$ & 0,727 \\
\hline KB4 & $<--$ & Intensi_Berwisata & $.894^{* *}$ & 0,932 \\
\hline KB5 & $<--$ & Intensi_Berwisata & $.876^{* *}$ & 0,966 \\
\hline KB6 & $<--$ & Intensi_Berwisata & $.887^{* *}$ & 0,963 \\
\hline
\end{tabular}

Sumber : Data Sekunder Diolah (2020)

Berdasarkan nilai Pearson Correlation, semua item dinyatakan valid karena memiliki nilai r-hitung $>r$ tabel. R-tabel yang menjadi acuan adalah 0,1519 dengan uji signifikan 0,05. Nili r-hitung paling rendah adalah indikator KB1 yaitu 0,563. Pengujian validias dengan menggunakan loading factor dari standardized regression weights juga menunjukkan semua indikator dinyatakan valid kecuali indikator KB1 karena memiliki nilai loading factor sebesar 0,212. Hal ini menunjukan indikator KB1 memiliki hubungan korelaasi yang paling lemah terhadap varibel KB.

\section{Uji Reliabilitas}

Uji Reliabilitas dilakukan untuk menguji konsistensi internal indikator yang akan mempengaruhi variabel penelitian. Dalam melakukan uji reliabilitas, peneliti mengacu pada nilai dari cronbach alpha yang didapat dari program SPSS dan juga construct reliability yang didapatkan dari hasil standardized loading pada program AMOS. Nilai acuan dari dari construct reliability adalah minimal 0,70 (Ghozali, 2006). Dikarenakan AMOS tidak mengeluarkan nilai construct reliability, dilakukan perhitungan sendiri dengan menggunakan formulasi sebagai berikut:

Tabel 3. Uji Reliabilitas

\begin{tabular}{lll} 
Variabel & Cronbach Alpha & CR \\
\hline Risiko Keuangan & 0,844 & 0,8465 \\
Risiko Waktu & 0,882 & 0,9092 \\
Risiko Sosial Psikologi & 0,959 & 0,9546 \\
Risiko Kesehatan & 0,926 & 0,9585 \\
Intensi Berwisata & 0,892 & 0,8697 \\
\hline
\end{tabular}

Sumber : Data Sekunder Diolah (2020) 
Dengan mengacu kepada nilai cronbach alpha 0,7, maka dapat disimpulkan jika semua indikator reliabel. Hal ini juga didukung dengan perhitungan semua nilai construct reliability di atas 0,70 . Hal ini menunjukan terdapatnya konsistensi dalam mengukur variabel konstruk.

\section{Uji Goodness of Fit}

Hasil dari analisis jalur dari model penelitian adalah sebagai berikut

Gambar 2. Uji Goodness of Fit

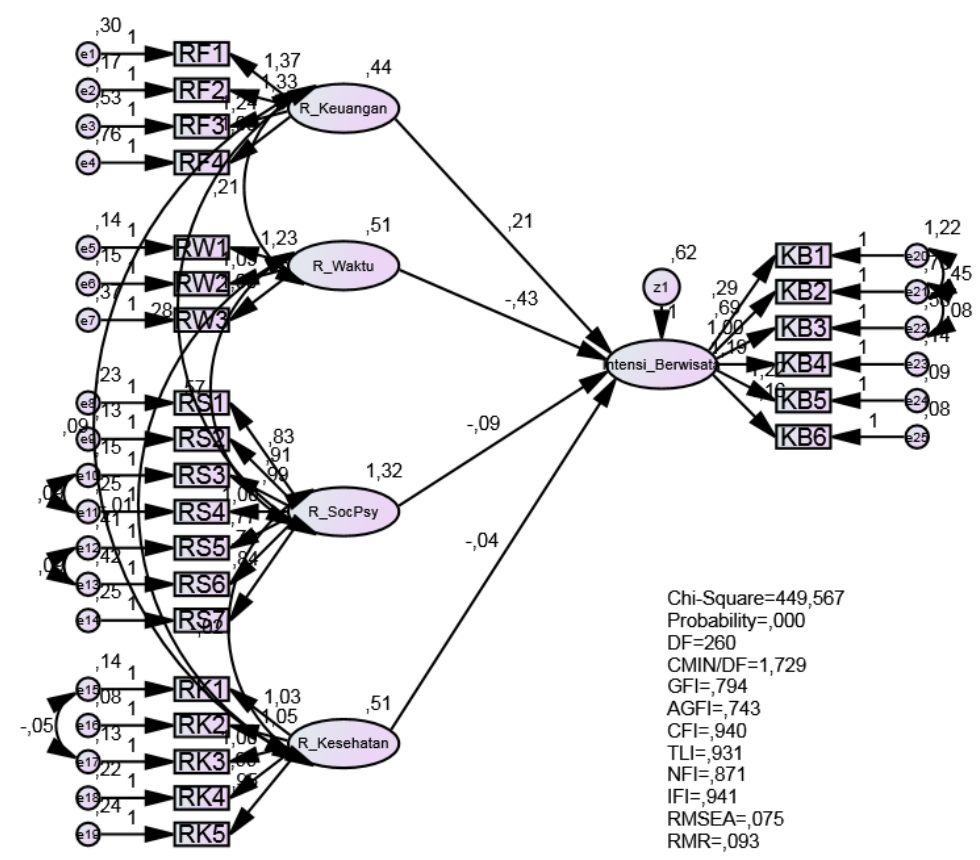

Uji ini dilakukan untuk mengetahui apakah model fit dengan data yang diperoleh. Uji ini juga akan melihat apakah model persamaan struktural dapat diterima atau tidak.

Tabel 4. Uji Goodness of Fit

\begin{tabular}{|c|c|c|c|}
\hline \multicolumn{2}{|c|}{ Kriteria Goodness of Fit } & Hasil & \multirow[t]{2}{*}{ Kesimpulan } \\
\hline \multicolumn{3}{|c|}{ Uji Kecocokan Absolut } & \\
\hline$\overline{X^{2} \text { (Chi-Square) }}$ & Rendah jika $P>0.05$ & $449,567, P=0.000$ & Poor Fit \\
\hline CMIN/DF & $\begin{array}{l}\text { Good Fit jika CMIN/DF } \leq 2 \\
\text { Marginal Fit jika } 2<\text { CMIN/DF } \leq 5\end{array}$ & 1.729 & Good Fit \\
\hline GFI & $\begin{array}{l}\text { Good Fit jika GFI } \geq 0.90 \\
\text { Marginal Fit jika } 0.80 \leq \mathrm{GFI}<0.90\end{array}$ & 0,794 & Marginal Fit \\
\hline RMSEA & $\begin{array}{l}\text { Good Fit jika } 0.05 \leq \text { RMSEA } \leq 0.08 \\
\text { Marginal Fit jika } 0.08 \leq \text { RMSEA } \leq 0.1\end{array}$ & 0.075 & Good Fit \\
\hline RMR & Marginal Fit jika RMR $\leq 0,10$ & 0.093 & Marginal Fit \\
\hline \multicolumn{4}{|c|}{ Uji Kecocokan Incrementl } \\
\hline$\overline{\mathrm{AGFI}}$ & $\begin{array}{l}\text { Good Fit jika AGFI } \geq 0.90 \\
\text { Marginal Fit jika } 0.80 \leq \mathrm{AGFI}<0.90\end{array}$ & 0.743 & Marginal Fit \\
\hline TLI & $\begin{array}{l}\text { Good Fit jika TLI } \geq 0.90 \\
\text { Marginal Fit jika } 0.80 \leq T L I<0.90\end{array}$ & 0.931 & Good Fit \\
\hline $\mathrm{CFI}$ & $\begin{array}{l}\text { Good Fit jika CFI } \geq 0.90 \\
\text { Marginal Fit jika } 0.80 \leq C F I<0.90\end{array}$ & 0.935 & Good Fit \\
\hline NFI & $\begin{array}{l}\text { Good Fit jika NFI } \geq 0.90 \\
\text { Marginal Fit jika } 0.80 \leq \mathrm{NFI}<0.90\end{array}$ & 0.940 & Good Fit \\
\hline IFI & $\begin{array}{l}\text { Good Fit jika IFI } \geq 0.90 \\
\text { Marginal Fit jika } 0.80 \leq|F|<0.90\end{array}$ & 0.941 & Good Fit \\
\hline
\end{tabular}


Dari hasil uji goodness of fit dengan menggunakan software AMOS, maka dapat disimpulkan bahwa model penelitian yang dikembangkan sudah baik. Hal ini ditunjukkan oleh hasil pengukuran nilai TLI, CFI NFI dan IFI yang $\geq 0.90$ merupakan good fit, nilai GFI dan AGFI antara 0.70 dan 0.80 yang merupakan marginal fit dan nilai RMSEA yaitu 0,075 yang menandakan good fit.

\section{Uji Hipotesis}

Uji ini dilakukann dengan mengacu kepada nilai Critical Ratio (CR) pada regression weights dan nilai probability antar variabel di AMOS. Hipotesis akan diterima jika nilai $C R$ lebih besar dari nilai 1,65 (dengan tingkat signifikansi 0,05 ). Sebaliknya hipotesis akan ditolak jika nilai $C R$, tidak melampaui 1,65 . Selain itu, pengaruh signifikansi atau tidaknya dapat dilihat dari nilai acuan $p$-value (jika $p$-value $\leq 0,05$ maka hipotesis diterima).

Tabel 5. Uji Hipotesis

\begin{tabular}{lclccccc} 
& & & Estimate & S.E. & C.R. & P & Keterangan \\
\hline Intensi_Berwisata & $<---$ & R_Keuangan & 0,201 & 0,131 & 1,537 & 0,124 & Ditolak \\
Intensi_Berwisata & $<---$ & R_Waktu & $-0,422$ & 0,159 & $-2,651$ & 0,008 & Ditolak \\
Intensi_Berwisata & $<---$ & R_SocPsy & $-0,092$ & 0,089 & $-1,038$ & 0,299 & Ditolak \\
Intensi_Berwisata & $<---$ & R_Kesehatan & $-0,037$ & 0,101 & $-0,365$ & 0,715 & Ditolak \\
\hline
\end{tabular}

Sumber : Data Sekunder Diolah (2020)

Dari hasil pengolahan data dapat disimpulkan:

1. Hipotesis H1: Peningkatan Risiko Keuangan berdampak negatif terhadap Intensi Berwisata.

Hasil penelitian menunjukan nilai C.R sebesar $1,537<1,65$ dan nilai $P$ value $=0,124>0,05$. Sehingga dapat disimpulkan bahwa $\mathrm{H} 1$ ditolak. Peningkatan Risiko keuangan tidak berdampak terhadap penurunan intensi untuk berwisata. Dalam penelitian dibidang keputusan investasi yang dilakukan oleh Pradikasari \& Isbanah (2018), menunjukan hal yang sama, yaitu persepsi risiko keuangan tidak memiliki pengaruh kepada keputusan investasi. Hal ini didukung oleh penelitian Lestari (2013) yaitu persepsi risiko keuangan tidak berpengaruh pada pengambilan keputusan investasi wirausaha.

2. Hipotesis H2: Peningkatan Risiko Waktu berdampak negatif terhadap Intensi Berwisata.

Hasil penelitian menunjukan nilai C.R sebesar $-2,651<1,65$ dan nilai $P$ value $=0,008<0,05$. Hal ini menunjukan bahwa hipotesa $\mathrm{H} 2$ ditolak yaitu tidak ada hubungan antara peningkatan risiko waktu dengan intensi berwisata

3. Hipotesis H3: Peningkatan Risiko Sosial-Psikologis berdampak negative terhadap Intensi Berwisata

Hasil penelitian menunjukan nilai C.R sebesar $-1,038<1,65$ dan nilai $P$ value $=0,299>0,05$ menjelaskan bahwa hipotesa $\mathrm{H} 3$ ditolak yaitu tidak ada hubungan antara peningkatan risiko sosial psikologi dengan intensi berwisata

4. Hipotesis H4: Peningkatan Risiko Kesehatan berdampak negatif terhadap Intensi Berwisata

Hasil penelitian menunjukan nilai C.R sebesar $-0,365<1,65$ dan nilai $P$ value $=0,715>0,05$. Hal ini menunjukkan hipotesa ditolak yaitu tidak ada hubungan antara peningkatan risiko kesehatan dengan intensi berwisata

Secara umum, penelitian ini sejalan dengan penelitian yang dilakukan oleh Kurniawan et al. (2016) yaitu persepsi risiko tidak berpengaruh terhadap citra merek, walaupun citra merek memiliki pengaruh positif terhadap keputusan pembelian. Dalam kontek berwisata, penelian ini juga mendukung penelitian Suardana (2017), persepsi risiko tidak signifikan berperan sebagai pemoderasi pada hubungan kepercayaan dan niat berperilaku wisatawan. Lebih lanjut dikatakan jika wisatawan yang memiliki kecenderungan persepsi risiko wisata diving ke bali kecil tidak akan berpengaruh dalam meningkatkan kepercayaan untuk berwisata ke bali, walaupun persepsi ini berpengaruh kepada peningkatan kepuasan dan niat berwisata. Di industri otomotif, Henricus Adi \& Farida (2018) juga mengemukakan jika persepsi risiko tidak berpengaruh terhadap intensi pembelian motor. Penelitian ini memperkuat hasil penelitian Chen et al. (2017), yang tidak menemukan pengaruh signifikan persepsi risiko terhadap intensi pembelian. 


\section{Kesimpulan}

Dari hasil keseluruhan data yang telah diolah dan diuji diperoleh kesimpulan bahwa keempat hipotesa di tolak. Uji hipotesa yang dilakukan terhadap responden yang 79,9\% berusia 16-25 tahun, ditemukan tidak adanya pengaruh langsung antara persepsi risiko terhadap intensi berwisata. Peningkatan persepsi risiko, baik itu risiko keuangan, risiko waktu, risiko sosial psikologi dan juga risiko kesehatan tidak berpengaruh langsung terhadap intensi berwisata. Diantara 4 variabel yang diuji, persepsi risiko keuangan $(0,16)$ memiiki pengaruh yang paling besar, diikuti oleh persepsi risiko kesehatan $(-0,032)$, risiko sosial psikologi $(-0,127)$ dan terakhir risiko waktu $(-$ $0,363)$.

\section{Daftar Pustaka}

Artuğer, S. (2015). The Effect of Risk Perceptions on Tourists ' Revisit Intentions. European Journal of Business and Management, $7(2)$.

Bae, S. Y., \& Chang, P. J. (2020). The effect of coronavirus disease-19 (COVID-19) risk perception on behavioural intention towards 'untact' tourism in South Korea during the first wave of the pandemic (March 2020). Current Issues in Tourism, 0(0), 1-19. https://doi.org/10.1080/13683500.2020.1798895

Beirman, D. (2002). Marketing of tourism destinations during a prolonged crisis: Israel and the Middle East. Journal of Vacation Marketing, 8(2), 167-176. https://doi.org/10.1177/135676670200800206

Boyraz, G., \& Legros, D. N. (2020). Coronavirus Disease (COVID-19) and Traumatic Stress: Probable Risk Factors and Correlates of Posttraumatic Stress Disorder. Journal of Loss and Trauma, 0(0), 1-20. https://doi.org/10.1080/15325024.2020.1763556

Brewer, N. T., Chapman, G. B., Gibbons, F. X., Gerrard, M., McCaul, K. D., \& Weinstein, N. D. (2007). Metaanalysis of the relationship between risk perception and health behavior: The example of vaccination. Health Psychology, 26(2), 136-145. https://doi.org/10.1037/0278-6133.26.2.136

Brewer, N. T., \& Fazekas, K. I. (2007). Predictors of HPV vaccine acceptability: A theory-informed, systematic review. Preventive Medicine, 45(2-3), 107-114. https://doi.org/10.1016/j.ypmed.2007.05.013

Chen, H. S., Tsai, B. K., \& Hsieh, C. M. (2017). Determinants of consumers' purchasing intentions for the hydrogen-electric motorcycle. Sustainability (Switzerland), 9(8), 1-12. https://doi.org/10.3390/su9081447

Chew, E. Y. T., \& Jahari, S. A. (2014). Destination image as a mediator between perceived risks and revisit intention: A case of post-disaster Japan. Tourism Management, 40, 382-393. https://doi.org/10.1016/j.tourman.2013.07.008

Choi, K. H., Kim, M., \& Leopkey, B. (2019). Prospective tourists' risk perceptions and intentions to travel to a mega-sporting event host country with apparent risk. Journal of Sport and Tourism, 23(2-3), 97-114. https://doi.org/10.1080/14775085.2020.1715826

Featherman, M. S., \& Pavlou, P. A. (2003). Predicting e-services adoption: A perceived risk facets perspective. International Journal of Human Computer Studies, 59(4), 451-474. https://doi.org/10.1016/S10715819(03)00111-3

Gut, P., \& Jarrell, S. (2007). Silver lining on a dark cloud: The impact of 9/11 on a regional tourist destination. Journal of Travel Research, 46(2), 147-153. https://doi.org/10.1177/0047287507299590

Hasan, M. K., Ismail, A. R., \& Islam, M. F. (2017). Tourist risk perceptions and revisit intention: A critical review of literature. Cogent Business and Management, 4(1). https://doi.org/10.1080/23311975.2017.1412874

Henricus Adi, K., \& Farida, I. (2018). Pengaruh Product knowledge, Perceived Quality, Perceived Risk, Dan Perceived Value Terhadap Purchase Intention pada Motor Kawasaki Ninja 250 Fi Di Kota Semarang. Diponegoro Journal of Management, 7(4), 1-13

Jun, S. H. (2020). The effects of perceived risk, brand credibility and past experience on purchase intention in the Airbnb context. Sustainability (Switzerland), 12(12). https://doi.org/10.3390/su12125212

Khan, Mohammad J., Chelliah, S., Haron, M. S., \& Ahmed, S. (2017). Role of travel motivations, perceived risks and travel constraints on destination image and visit intention in medical tourism: Theoretical model. Sultan Qaboos University Medical Journal, 17(1), e11-e17. https://doi.org/10.18295/squmj.2016.17.01.003

Khan, Mohammad Jamal, Chelliah, S., \& Ahmed, S. (2017). Factors influencing destination image and visit intention among young women travellers: role of travel motivation, perceived risks, and travel constraints. Asia Pacific Journal of Tourism Research, 22(11), 1139-1155. https://doi.org/10.1080/10941665.2017.1374985 
Khan, Mohammad Jamal, Chelliah, S., Khan, F., \& Amin, S. (2019). Perceived risks, travel constraints and visit intention of young women travelers: the moderating role of travel motivation. Tourism Review, 74(3), 721738. https://doi.org/10.1108/TR-08-2018-0116

Khasawneh, M. S., \& Alfandi, A. M. (2019). Determining behaviour intentions from the overall destination image and risk perception. Tourism and Hospitality Management, 25(2), 355-375. https://doi.org/10.20867/thm.25.2.6

Kozak, M., Crotts, J. C., \& Law, R. (2007). The impact of the perception of risk on international travellers. International Journal of Tourism Research, 9(4), 233-242. https://doi.org/10.1002/jtr.607

Kurniawan, T., Soesanto, H., \& Sufian, S. (2016). Pengaruh Persepsi Nilai, Brand Awareness \& Persepsi Risiko Terhadap Keputusan Mengambil Kredit Pensiunan yang Dimediasi Oleh Citra Merek di Bank Bukopin Cabang Semarang. Universitas Dipenegoro. http://eprints.undip.ac.id/50106/

Laroche, M., Mcdougall, G. H. G., Bergeron, J., \& Yang, Z. (2004). Exploring How Intangibility Affects Perceived Risk. Journal of Service Research, 6(4), 373-389. https://doi.org/10.1177/1094670503262955

Lee, C. K., Song, H. J., Bendle, L. J., Kim, M. J., \& Han, H. (2012). The impact of non-pharmaceutical interventions for $2009 \mathrm{H} 1 \mathrm{~N} 1$ influenza on travel intentions: A model of goal-directed behavior. Tourism Management, 33(1), 89-99. https://doi.org/10.1016/j.tourman.2011.02.006

Lestari, W. (2013). Religiusitas Dan Persepsi Risiko Dalam Pengambilan Keputusan Investasi Pada Perspektif Gender. Journal of Business and Banking, 3(2), 189. https://doi.org/10.14414/jbb.v3i2.236

Loewenstein, G. F., Hsee, C. K., Weber, E. U., \& Welch, N. (2001). Risk as Feelings. Psychological Bulletin, 127(2), 267-286. https://doi.org/10.1037/0033-2909.127.2.267

Matzler, K., Strobl, A., Stokburger-Sauer, N., Bobovnicky, A., \& Bauer, F. (2016). Brand personality and culture: The role of cultural differences on the impact of brand personality perceptions on tourists' visit intentions. Tourism Management, 52, 507-520. https://doi.org/10.1016/j.tourman.2015.07.017

McLeay, F., Yoganathan, V., Osburg, V. S., \& Pandit, A. (2018). Risks and drivers of hybrid car adoption: A cross-cultural segmentation analysis. Journal of Cleaner Production, 189, 519-528. https://doi.org/10.1016/j.jclepro.2018.04.031

Mitchell, V. W., \& Vassos, V. (1998). This article was downloaded by : [ German National Licence 2007 ] Access details : Access Details : [ subscription number 777306418 ] Publisher Routledge Informa Ltd Registered in England and Wales Registered Number : 1072954 Registered office : Mortimer. Journal of Euromarketing, 6(3), 47-79. https://doi.org/10.1300/J037v06n03

Moutinho, L. (2007). Article information: Abstract and Keywords. In European Journal of Marketing (Vol. 21, Issue 10).

Neuburger, L., Egger, R., \& Neuburger, L. (2020). Current Issues in Tourism Travel risk perception and travel behaviour during the COVID-19 pandemic 2020 : a case study of the DACH region pandemic 2020 : a case study of the DACH region. Current Issues in Tourism, 0(0), 1-14. https://doi.org/10.1080/13683500.2020.1803807

Pine, R., \& McKercher, B. (2004). The impact of SARS on Hong Kong's tourism industry. International Journal of Contemporary Hospitality Management, 16(2), 139-143. https://doi.org/10.1108/09596110410520034

PRADIKASARI, E., \& ISBANAH, Y. (2018). Pengaruh Financial Literacy, Illusion of Control, Overconfidence, Risk Tolerance, dan Risk Perception Terhadap Keputusan Investasi Pada Mahasiswa di Kota Surabaya. Jurnal IImu Manajemen (JIM), 6(4), 424-434.

Promsivapallop, P., \& Kannaovakun, P. (2018). Travel risk dimensions, personal-related factors, and intention to visit a destination: a study of young educated German adults. Asia Pacific Journal of Tourism Research, 23(7), 639-655. https://doi.org/10.1080/10941665.2018.1485718

Quintal, V. A., Lee, J. A., \& Soutar, G. N. (2010). Risk, uncertainty and the theory of planned behavior: A tourism example. Tourism Management, 31(6), 797-805. https://doi.org/10.1016/j.tourman.2009.08.006

Reisinger, Y., \& Mavondo, F. (2005). Travel anxiety and intentions to travel internationally: Implications of travel risk perception. Journal of Travel Research, 43(3), 212-225. https://doi.org/10.1177/0047287504272017

Rittichainuwat, B. N., \& Chakraborty, G. (2009). Perceived travel risks regarding terrorism and disease: The case of Thailand. Tourism Management, 30(3), 410-418. https://doi.org/10.1016/j.tourman.2008.08.001

See, G. T., \& Goh, Y. N. (2019). Tourists' intention to visit heritage hotels at George Town World Heritage Site. Journal of Heritage Tourism, 14(1), 33-48. https://doi.org/10.1080/1743873X.2018.1458853 
Sharifpour, M., Walters, G., Ritchie, B. W., \& Winter, C. (2014). Investigating the Role of Prior Knowledge in Tourist Decision Making: A Structural Equation Model of Risk Perceptions and Information Search. Journal of Travel Research, 53(3), 307-322. https://doi.org/10.1177/0047287513500390

Sonmez, S. F., \& Graefe, A. R. (1998). Determining future travel behavior from past travel experience and perceptions of risk and safety. Journal of Travel Research, 37(2), 171-177. https://doi.org/10.1177/004728759803700209 